\title{
YOU MEET \\ THE MOST INTERESTING PEOPLE
}

\author{
By Lida L. Greene \\ Librarian of Iowa State Historical Library
}

It's summer again. The church tower, sighted from the north windows of the Library, is framed in the green lace of leaves. Fans whir. The Little General, in his portrait on the wall, solemnly marshalls an unseen parade.

School is over. America is on wheels. The library register for patrons shows a growing roster of other state-and even other country - addresses. From Ontario, Canada - Brother Peter Webbers; from California, Utah, and points west-Stanley Hirshson, historian, of New Jersey. Oddly enough, Mr. Hirshson brought with him the ghost of old Jim Bridger.

Four years ago, Stanley Hirshson spent two and a half months surrounded by black boxes that held the papers of Granville M. Dodge. This coming winter, 1967, his biography of the Little General will be published by the University of Indiana Press. In June he was hard on the trail of Brigham Young, the lure of another book in mind. That is how he happened to conjure up the redoubtable Bridger.

"There's a letter from Bridger to Dodge in this stuff someplace," he told us. He went on to say something about Grenville Dodge being the authority on Jim Bridger, but I didn't really listen. I had stopped short with that Bridger letter.

Jim Bridger, you will recall, invaded the West when the Yellowstone was as far from civilization as Cathay from a Columbus-farther, perhaps, than the mountains of the moon from the drawing board of the space scientist. Jim Bridger was an explorer, raconteur, king of the mountain men-to discover a letter from Jim Bridger to Grenville Dodge, even though written by an unknown scribe, is like making a gold strike, or like finding a nugget of the Old West under the corner of the Historical Building. 
Some day we hope to have a case where we can display items like the Bridger letter. Until then, consider Jim Bridger a lure across the path of your summer. It's another invitation to stop by and see us. So you're not a Bridger buff? Pick out your own memorable person. Lewis and Carolyn Johnstone of Cincinnati did. Last summer they came to learn more about Edward Johnstone of Keokuk, great-great-grandfather and signer of the 1857 Iowa Constitution. Then there was Agnes Dungan Kreutzberg of Cleveland who arrived early in May to delve into the papers of Warren Scott Dungan, lieutenant governor of Iowa, 1894-1896.

If we do say so, your Historical Library is a good place to visit. You meet the most interesting people.

\section{LETTERS . . .}

We recently received a letter which is of interest because it concerns a common error of thought about the Indians of Iowa. It asked:

with the question: Do the Indians in Iowa live on a reservation or in a settlement?

Dear Sirs:

In studying Iowa History I have been confronted All reference material, i.e., WORLD BOOK ENCYCLOpedia, Iowa the Land Across the River, and Iowa ROAD MAPs list it as a reservation but I thought that since they (the Indians) bought this land and own it themselves, it therefore is not a reservation.

Will you give me an answer in view of this fact.

Sincerely, Mrs. Ruby M. James

The Indians in Iowa do not live on reservations, but on privately owned land which is handled as a collective farm. To call this land a reservation is incorrect. ${ }^{1}$

${ }^{1}$ William J. Petersen, The Story of Iowa (New York, 1952), I, 146. 
Copyright of Annals of Iowa is the property of State of Iowa, by \& through the State Historical Society of Iowa and its content may not be copied or emailed to multiple sites or posted to a listserv without the copyright holder's express written permission. However, users may print, download, or email articles for individual use. 